\title{
The Influence of Inflation, Exchange Rate, and Foreign Exchange Reserves on the Ship Unloading of Garlic Threw Surabaya Harbour
}

\author{
Afifuddin Abha \\ University Merdeka Malang, Indonesia
}

\begin{abstract}
Indonesia is known as one of the world's largest spice-producing countries which was once had self-sufficiency in garlic, but now have to import garlic from abroad to meet the needs of domestic garlic. Surabaya is the capital city of East Java Province in Indonesia known as the center of Eastern Indonesia which has a substantial contribution to the national economy. This research attempts to analyze the influence of inflation, Rupiah exchange rate and foreign exchange reserves towards the ship unloading of garlic simultaneously and partially. Analysis technique used are multiple linear regression analysis method and for the hypothesis test, F-test and t-test are used with significance level of $5 \%$. As for the classic assumption test, this research uses normality test, multicollinearity test, autocorrelation test and heteroscedasticity test. This research uses secondary data obtained from Statistic Bureau of East Java. The simultaneous test by F-test shows that inflation, rupiah exchange rate, and foreign exchange reserves significantly influence the import of garlic in East Java over the year 2012-2017 but foreign exchange reserves does not significantly influence the ship unloading of garlic threw Surabaya Harbour over the year 2012-2017.
\end{abstract}

Keywords: Inflation, Rupiah Exchange, Foreign Exchange Reserves, Garlic, Ship Unloading, Surabaya Harbour.

\section{INTRODUCTION}

Indonesia is an agrarian country because most of its people have livelihood as farmers. The fertile soil makes Indonesia rich with a variety of agricultural crops, including spices. Since the ancient times, Indonesiais know as one of the world's largest spice-producing countries. This has led Indonesia into one of the world's trade center in the $15^{\text {th }}$ century. Even before indonesia's independence, many foreign countries to colonize indonesia because of wealth of its spices.

There is one spice that can not be separated from the culinary world which exists in almost every Indonesia cuisine and even cuisine from different parts of the world, which is garlic. Not only as a spice, garlic from centuries ago has been used in the medical world especially in China. The contet of compounds in garlic is potent against various diseases. This is due to the greatest content of allicin compounds in garlic. Allicin is an active compound in garlic that is unstable and effectively kills microbes, such as infectious germs (flu, gastroenteritis and fever). Based on the facts described above, it is no wonder that horticulture becomes an important an strategic commodity group because the commodity is one of the human needs. The need for garlic necessarily increase along with the increase of population. Based on Wikipedia, the population of Indonesia as of 2016 as many as 261,115,456 inhabitants. With a population of this much, of course the need for garlic is also high which makes garlic an agricultural commodity with a great level of consumption. But what is quite surprising is that as one of the world's largest producer of spices, indonesia has to import garlic every year from other countries to meet domestic demand, even every year tends to increase. The following is the 
total import of garlic, garlic production and annual garlic consumtion per capita in Indonesia over the period of 2012-2016.

Table 1. Total Ships Unloading Of Garlic Period 2012-2016

\begin{tabular}{|c|c|c|c|}
\hline Year & $\begin{array}{c}\text { Ships unloading of Garlic } \\
\text { threw indonesia } \\
\text { harbours(ton) }\end{array}$ & $\begin{array}{c}\text { Garlic } \\
\text { Production } \\
\text { (ton) }\end{array}$ & $\begin{array}{c}\text { Annual Garlic } \\
\text { Consumption } \\
\text { per capita (ton) }\end{array}$ \\
\hline 2012 & 448,098 & 17,630 & 124,450 \\
\hline 2013 & 442,767 & 15,767 & 95,760 \\
\hline 2014 & 494,631 & 16,892 & 124,999 \\
\hline 2015 & 482,665 & 20,294 & 140,977 \\
\hline 2016 & 448,881 & 21,150 & 144,127 \\
\hline
\end{tabular}

Source: Badan Pusat Statistik (BPS) and The Ministry of Agriculture, Processed

Based on the data above, it can be concluded that Indonesia is only able to meet the demand for garlic by roughly $15 \%$ with the production of roughly 15.000 tons every year. The import of garlic of roughly 400.000 tons each year is the reason for the dependence on imported garlic. Even in 2014, the Head of Horticultural of Himpunan Kerukunan Tani Indonesia (HKTI) Benny Kusbini said that Indonesia is the largest garlic importer in the world and China is actually the largest garlic producing country in the world with production of milions of tons per year (Indonesia Import Bawang Putih Terbesar di Dunia. 2014, March 4. Retrieved December 7, 2017, from https://finance.detik.com).

The increasing in import of garlic in Indonesia ( also in East Java ) accompanied by the fluctuation of inflation rate, the fluctuation of rupiah exchange rate against US Dollar and also the development of the foreign exchange reserves becomes the driving force that encourage the importance to be studied and analysed what are the factors that influence the import of garlic in East Java from year to year. The results of this study can be used as an additional reference to determine the policy on the import of garlic Indonesia, particularly in East Java. Therefore, this research was conducted to determine and describe how significant is the inflation, exchange rate and foreign exchange reserves on the import of garlic in East Java. This research study created with the title " The influence of Inflation, Exchange Rate and Foreign Exchange Reserves on the Import of Garlic in East Java". Based on the background of the problem mentioned earlier, the research problem is as follow: (1) Does the inflation, exchange rate and foreign exchange reserves simultaneously influence the import of garlic in East java significantly? (2) Does the inflation, exchange rate and foreign exchange reserves partially / individually influence the Import of garlic in East Java significantly? According to the formulation of the problem mentioned earlier, the purpose of this research are: (1) To determine whether the inflation, exchange rate and foreign exchange reserves simultaneously influence the import of garlic in East java significantly or not ? (2) To determine whether the inflation, exchange rate and foreign exchange reserves partially / individually influence the Import of garlic in East Java significantly or not?

\section{Inflation}

\section{LITERATURE REVIEW}

Indonesia's inflation is caused by several factors, among others, the Central Government of INDONESIA or the local government in their respective provincial/district/city due to the Insistence and demos from the Rush then the UMR (Regional Minimum Wage) of the province of/Cities in this direct impact and raise push inflation pressure because the salary/wages that will increase the purchasing power of the consumer society in General so that prices will move up. should ideally demos rush who demanded salary increases then the rush should be able to 
increase the productivity of goods/services so the money circulating in the communities is still balanced with the procurement of goods and services in the market so the prices do not increase the fact in Indonesia salary/increased productivity in no follow with so the price of goods and services in General is moving up and suppress inflation rate.

\section{Foreign Exchange Rate}

Likewise, the relationship between private parties between the Indonesian private party with other countries (Personal to Personal) for example in this case in Indonesia, namely the export and import transactions or transactions with the flow of goods or services which are all current in a calculation taking into account the exchange rate between the Rupiah and the US Dollar, the currency of transaction flows of goods export import example results of industry products (among other equipment factory machinery, textiles, and more). The result mining (iron, coal, fuel oil, LPG gas), agriculture (rice, corn, wheat, rice brand, pelletizing, Crude Oil and other pahlem), forestry (e.g., teak, timber, iron, wood wooden camphor, suren, wood rattan, resin, furniture and other), the results of the fishery (e.g. tuna, lobster, tiger prawns, shark fin, crab, red snapper, and more) while the flow of services in sales Indonesia traded with other countries (marine services cargo insurance i.e. insurrance boatload of sea the mining ship/shipping freight ships, the service fees sea port, freiht aircraft which have routes between countries, Onkos-fare service of the port State, the results of investment outside the country, the results of the securities purchased from the foreign shareholding arrangements, the results of the pituang foreign exchange abroad, and others. In Indonesia if the rupiah weakened against the US Dollar or the rupiah strengthened against the US dollar

\section{Foreign exchange reserves}

unilaterally CDN will be charged by the State of export proceeds investment outside the country proceeds, proceeds receivable-accounts receivable these countries into opposing the State, loans/debt-the debt of foreign countries, as well as the proceeds of the letters precious (stocks, bonds and other) shareholding arrangements abroad are in possession of the country. Indonesia's foreign exchange reserves so the country is relying on the relative export proceeds as well as on foreign exchange loans/debt-debt abroad, but in fact the export proceeds almost entirely used for buying imported goods for industrial use as well as for the purposes of consumption of people's staple Indonesia foreign exchange reserves of the country can be a foreign exchange and precious metals include gold, Platinum, and silver, and it was customary for all central banks around the world in other words foreign exchange reserves or CDN this was her wallet of the State and if the Government or businessmen Indonesia wanted to buy foreign goods (imports and the service) then must be paid with foreign currency owned by the foreign exchange reserves of the country.

\section{DATA ANALYSIS TECHNIQUE}

The data were analyzed using multiple linear regression assisted by SPSS software version 23 . The steps undertaken to analyze the research data are as follow:

\section{Determine The Equation Model}

According Sugiyono (2014: 191), multiple linear regression analysis aims to measure the influence of independent variables. Multiple linear regression is to show an independent relationship with two or more other independent variables.

$$
\mathrm{Y}=\alpha+\beta 1 \mathrm{X} 1+\beta 2 \mathrm{X} 2+\beta 3 \mathrm{X} 3+\mathrm{e}
$$

Information:

$\mathrm{Y}=$ Total import volume of garlic in East Java period of 2012-1016 
$\alpha=$ constant

$\beta 1,2,3,4=$ constant of independent variable

$\mathrm{Y}=$ Total import volume of garlic in East Java period of 2012-1016

$\mathrm{X} 1=$ Inflation rate period of 2012-2016

$\mathrm{X} 2$ = Rupiah exchange rate period of 2012-2016

$\mathrm{X} 3=$ Foreign exchange reserves period of 2012-2016

$\mathrm{e}=$ error term

\section{Hypothesis testing}

To test the effect of independent variables on the dependent variable using the $\mathrm{T}$ test and $\mathrm{F}$ test. $\mathrm{T}$ test is used to determine whether the independent variable partially has a significant influence on the dependent variable, while the $\mathrm{F}$ test is used to test whether an independent variable simultaneously effects significantly on the dependent variable.

\section{Results of Multiple Linear Regression Analysis}

\section{RESULTS AND DISCUSSION}

Based on calculations by the supporting tool SPSS version 23, the obtained results are shown below

Table 1. Results of Multiple Linear Regression Analysis

\begin{tabular}{|c|c|c|c|c|c|}
\hline \multirow[b]{2}{*}{ Model } & \multicolumn{2}{|c|}{ Unstandardized Coefficients } & $\begin{array}{l}\text { Standardized } \\
\text { coefficients }\end{array}$ & $\mathrm{t}$ & Sig. \\
\hline & $\mathrm{B}$ & Std.Error & Beta & & \\
\hline (Constant) & $-10849761,64$ & 107972800,01 & &,- 100 & -920 \\
\hline Inflation (X1) & 18996546,870 & 8715645,204 & ,279 & 2,180 & 034 \\
\hline Exchange Rate (X2) & 6658,107 & 3147,323 & ,265 & 2,115 & 039 \\
\hline $\begin{array}{l}\text { Foreign Exchange } \\
\text { Reserves (X3) }\end{array}$ & $-351,021$ & 928,490 &,- 048 &,- 378 & ,707 \\
\hline
\end{tabular}

a. Dependent variable: Import of garlic in East Java (Y)

According to the result shown above, it can be seen that the Multiple linear Regression Analysis equation is as follow:

$$
Y=-10849761,645+18996546,870 X 1+6658,107 X 2-351,021) X 3
$$

\section{Hypothesis Test}

After all data is collected and processed in SPSS 20 software,the researcher gets the following result:

\section{Determinant Coefficient Test (R2)}

The determinant coefficient test is used to find out how big the relationship of some variables in a clearer sense. The determinant coefficient test will explain how much change or variation of a variable can be explained by changes or variation of other variables ( Santosa \& Ashari ,2005:125). And after the data is processed in SPSS 20,the result is as follows:

Table 2. Model Summary

\begin{tabular}{|c|c|c|c|c|}
\hline Model & \multicolumn{1}{|c|}{$\mathrm{R}$} & \multicolumn{1}{c|}{ R Square } & $\begin{array}{c}\text { Adjusted R } \\
\text { Square }\end{array}$ & $\begin{array}{c}\text { Std.Error of the } \\
\text { Estimate }\end{array}$ \\
\hline 1 &, $371 \mathrm{a}$ &, 138 &, 091 & 40003977,23126 \\
\hline
\end{tabular}

a.Predictors : (Constant), Foreign Exchange Reserves (X3), Exchange Rate (X2), Inflation (X1) 
Based on the above result, the determinant coefficient test $\left(\mathrm{R}^{2}\right)$ shows that the Ships onloading of garlic in East Java (Y) is influenced by Inflation $\left(\mathrm{X}_{1}\right)$,Exchange Rate between US Dollar against Indonesia Rupiah $\left(\mathrm{X}_{2}\right)$ and state Reserves $\left(\mathrm{X}_{3}\right)$ of 0.138 or $13.8 \%$. This means that $13.8 \%$ change in import volume of garlic in East Java $(\mathrm{Y})$ is influenced by Inflation $\left(\mathrm{X}_{1}\right)$ ,Exchange Rate between US dollar against Indonesia Rupiah $\left(\mathrm{X}_{2}\right)$ and Foreign Exchange Recerves $\left(\mathrm{X}_{3}\right)$. While the that is equal to $86.2 \%$ influenced by other variables outside this research. The percentage of the determinant coefficient can be said to be weak because the determinant coefficient value $\left(\mathrm{R}^{2}\right)$ is less than $50 \%$ which means no significant effect.

\section{F- Test ( Simulataneous Hypothesis Testing )}

Table 3. ANOVAa

\begin{tabular}{|l|l|c|lc|l|l|}
\hline & & & & \\
Model & Sum of Squares & df & Mean Square & F & Sig. \\
\hline Regression & 14289341822245778,000 & 3 & 4763113940815 & 259,000 & 2,976 & ,039b \\
Residual & 89617818881890064,000 & 56 & 160031819 & 4319 & & \\
Total & 103907160704325840,000 & 59 & 286,800 & & & \\
\hline
\end{tabular}

a. Dependent Variable: Ships unloading of Garlic in East Java (Y)

b. Predictors: (Constant),Foreign Exchange Reserves (X3),Exchange Rate (X2),Inflation (X1)

From the table above, the value of $\mathrm{F}$ count amounted to 2.976 with a probability value (sig.) $=$ 0.039 . the value of F count $(2,976)>F$ table $(3 ; 56)(2,769)$ which means $H 4$ is accepted and $\mathrm{H} 04$ is rejected, and the sig. Value is smaller than probability value $(0,039)<(0,05), \mathrm{H} 4$ is accepted and H04 is rejected. That means Inflation (X1),Exchange Rate Between US Dollar Against Indonesia Rupiah (USD/IDR) (X2) and Foreign Exchange Reserves (X3) has a significant influence on the import volume of garlic in East Java (Y) simultaneously.

\section{T- Test ( Partial Hypothesis Testing)}

T-Test is used to partially test each variable. T- test results can be seen in the table coefficients on the significance (sig.) column. If the value of significance $<0.05$, the it can be said that there is a significant influence between independent variables on the variable tied partially.But if the significance value $>0.05$, no significant difference between independent variables and dependent variable partially.

Table 4. Coefficient Table as T-Test (Partial) Result Coefficients

\begin{tabular}{|c|c|c|c|c|c|}
\hline \multirow{2}{*}{ Model } & \multicolumn{2}{|c|}{ Unstandardized Coefficients } & \multirow{2}{*}{$\begin{array}{c}\begin{array}{c}\text { Standardized } \\
\text { Coefficients }\end{array} \\
\text { Beta }\end{array}$} & \multirow[t]{2}{*}{$\mathrm{t}$} & \multirow[t]{2}{*}{ Sig. } \\
\hline & B & Std.Error & & & \\
\hline (Constant) & - & 107972800,009 & &,- 100 & ,920 \\
\hline Inflation (X1) & $\begin{array}{l}10849761,645 \\
18996546,870\end{array}$ & 8715645,204 & ,279 & 2,180 & 034 \\
\hline Exchange Rate (X2) & 6658,107 & 3147,323 & 265 & 2,115 & ,039 \\
\hline $\begin{array}{l}\text { Foreign Exchange } \\
\text { Reserves (X3) }\end{array}$ & $-351,021$ & 928,490 &,- 048 &,- 378 & ,707 \\
\hline
\end{tabular}

a. Dependent Variable:Ships unloading of Garlic in East Java (Y)

\section{a.Inflation (X1) against beta (Y)}

Based on the result in the coefficient column,there is a sig. value of 0.034 . The sig. value is smaller than the probability value of $0.05(0.034<0.05)$ which means $\mathrm{H} 1$ is accepted and $\mathrm{H} 01$ 
is rejected. The $\mathrm{X} 1$ variable has $\mathrm{t}$ count value 2,180 with $\mathrm{t}$ table of 2.003 . It means $\mathrm{t}$ count value is bigger than $t$ table value $(2.180>2003)$ thus it can be concluded that the $X 1$ variable partially and significantly contributes to Y. The values above indicates that Inflation has a direct relationship with Beta .Thus it can be concluded that Inflation has a significant effect on Beta.

\section{b. Exchange Rate (USD/IDR) (X2) against beta (Y)}

Based on the results in the coofficient column, there is a sig. value of 0.039 . The sig. value is smaller than the probability value of $0.05(0.039<0.05)$ which means H2 is accepted and H02 is Rejected. The X2 variabble has t count value of 2.115 with t table of 2.003. It means $t$ count value is bigger than $t$ table value $(2.115>2.003)$ thus it can be concluded that the $\mathrm{X} 2$ variabble partially and significantly contributes to Y. The value above indicates that Exchange Rate Between US Dollar Against Indonesian Rupiah (USD/IDR) has a direct relantionship with Beta. Thus it can be concluded that Exchange Rate Between US Dollar Against Indonesian Rupiah ( USD/IDR) has a significant effect on Beta.

\section{c.Foreign Exchange Reserves (X3) against beta (Y)}

Based on the result in the coefficient column, there is a sig. value of 0.707 . The sig. value is bigger then the probability value of $0.05(0.707>0.05)$ which means H3 is rejected and H03 is accepted. The $\mathrm{X} 3$ variables has $t$ count value of -0.378 with $t$ table of 2.003 . It means $t$ count value is smaller than $t$ table value $(-.037<2.003)$ thus it can be concluded that the X3 variable partially and significantly has no contribution to $Y$.

\section{DISCUSSION}

From the above test results by using T-test (Partial Hypothesis Testing) it can be seen that inflation has a significant influence on the ships unloading of garlic in East Java. The result of this research are in accordance with previous research conducted by Rachmanti,Riyadi and Suharmanto (2016) entitled

"Pengaruh Inflasi dan Nilai Tukar Rupiah Terhadap Impor Kedelai di Jawa Tengah (Periode 2001-2013)" where the variable of inflation significantly influenced the import od soybean in central Java.

The relationship between these two variables is positive which can be interpreted that the change of inflation rate in Indonesia can influence the amount of garlic import in East Java. If there is an increase in inflation rate in Indonesia then the amount of ships unloading of garlic East Java will also experience an increase and vice versa if there is a decrease in the rate of inflation in Indonesia,The amount of ships unloading of garlic in East Java will also decreased.

From the above test result it can also be seen that exchange rate between US Dollar against Indonesia Rupiah (USD/IDR) has a significant influence on the ships unloading of garlic in East Java as well. The Result of this research are also in accordance with previous research conducted by by Muslim (2014) entitled "Faktor-faktor yang Mempengaruhi Nilai Impor Kedelai Indonesia" where the variable of Rupiah exchange rate in long term have a positive and significant influence on the value of Indonesia's soybean import.

The relationship between these two variable is positive which can be interpreted that the change of exchange rate between US Dollar against Indonesia Rupiah (USD/IDR) can influence the amount of garlic import in East Java. If there is an increase in exchange rate between US Dollar against Indonesia Rupiah (USD/IDR) then the amount of import volume of garlic in East Java will also experience an increase and vice versa if there is a decrease in the exchange rate 
between US Dollar against Indonesia Rupiah (USD/IDR),the amount of import volume of garlic East Java will also decreased.

From the above test result it can also be seen that foreign exchange reserves has no significant influence on the Ships unloading of garlic in East Java.

The result of this research are also in accordance with previous research conducted by by Zaeroni and Rustariyuni (2016) entitled "Pengaruh Produksi Beras, Konsumsi Beras dan Cadangan Devisa Terhadap Import Beras di Indonesia" where there variable of foreign exchange reserves have positive and significant influence to the import if rice in Indonesia.

The relationship between these two variables is negative which can be interpreted that the change of foreign exchange reserves will not influence the amount of garlic ships unloading of garlic in East Java. If there is an increase in the foreign exchange reserves then the amount of import volume of garlic in East Java will not experience an increase and vice versa if there is a decrease in the foreign exchange reserves, the amount of import volume of garlic in East Java will also not decreased.

On the other hand,by using F-test (Simultaneous Hypothesis) it can also be seen that inflation,exchange rate between US Dollar against Indonesia Rupiah (USD/IDR) and foreign exchange reserves has a significant influence on the import volume of garlic in East Java simultaneously.

\section{Conclution}

\section{CONCLUSIONS AND SUGGESTION}

Based on the results of research that has been done from data testing using the test model described in the previous chapter, it can be concluded that:

1. 1.Inflation, Exchange Rate between US Dollar against Indonesia Rupiah (USD/IDR) and Foreign Exchange Reserves $\left(\mathrm{X}_{3}\right)$ has an effect of $13.8 \%$ in effecting the ships unloading of garlic in East Java,while the rest the is equal to $86.2 \%$ influenced by other variables outside this research..

2. Inflation,Exchange Rate between US Dollar against Indonesia Rupiah (USD/IDR) and Foreign Exchange Reserves has a significant influence on the import volume of garlic in East Java (Y) simultaneously.

1. Inflation has a significant influence on the import volume of garlic in East Java (Y) partially. The result is derived from the partial hypothesis testing (T-test) where the value of $\mathrm{T}$ count amounted to 2,180 with a probability value (Sig.) $=0.034$.

2. Exchange Rate Between US Dollar against Indonesia Rupiah (USD/IDR) has a significant influence on the import volume off garlic in East Java $(Y)$ partially. The result is derived from the partial hypothesis testing (T-Test) where the value of $\mathrm{T}$ count amounted to 2,115 with a probability value (Sig.) $=0.039$.

3. Foreign Exchange Reserves has no significant influence on the import volume of garlic in East Java $(\mathrm{Y})$ partially. The result is derived from the partial hypothesis testing ( $\mathrm{T}$ Test) where the value of $\mathrm{T}$ count amounted to $-0,378$ with a probability value $(\mathrm{Sig})=$. 0,707 .

\section{Suggestion}

Based on the conclusions of the above research results, sugesstion that can be given are as follows: 
1. As can be seen aove,inflation,exchange rate between US Dollar against Indonesia Rupiah (USD/IDR) and foreign exchange reserves has a significant influence on the import volume of garlic in East Java simultaneously ,therefore if the government wants to reduce the volume of imports of garlic, then the government should give priority to policies that can control the rate of inflation to soar.

2. To the government as the implementer and controller of garlic import policy in Indonesia it is suggested to increase domestic garlic productivity by increasing domestic garlic import. It is expected that domestic garlic production is capable of developing and national consumption is not continuously dependent on the import of garlic itself.

3. For the next researcher, it is expected to analyze the factors that influence the demand for garlic import in Indonesia using more influential variables with more effective data analysis to obtain better result.

\section{References}

Arikunto, S. (2006). Metode Penelitian: Prosedur Penilitian Suatu Praktik.Jakarta: Rineka Cipta.

Dumairy (1996). Perekonomian Indonesia.Jakarta: Erlangga.

Fraenkel,J.R \& Wellen,N.E (2008). How to Design and Evaluate Research in Aducation. New York: Mc-Graw-Hill.

Ghozali, I (2009). Ekonometrika - Teori,Konsep dan Aplikasi dengan SPSS17. Semarang: Badan Penerbit Diponegoro.

Gilarso,T. (2004). Pengantar Ilmu Makro.Yogyakarta: Kanisius.

Hasan, M. (2008). Pokok-Pokok Materi Statestik 1 (Statistik Deskriptif). Jakarta: Bumi Aksara.

Marisa, F. (2014, June). Analisis Faktor-faktor yang Mempengaruhi Impor Bawang Putih di Indonesia Tahun 19802012.EconomicDevelopment Analysis Journal, 2, 235-242. Retrieved October 4th , 2017, from https://journal .unnes.ac.id/artikel_sju/edaj/3820.

Maleriansyah, Iskandar, S.\& Kurniawan, R. (2014,December). Analisis Faktor yang Mempengaruhi Volume Impor Dn Prodduksi Bawang Putih di Indonesia. Sociate, 3(2), 95-102. Retrieved October 4th ,2017, from Jurnal. Umpalembang.ac.id/ index.php/societa /article/download/61/36.

Muslim, A. (2014,July). Faktor-faktor yang Mempengaruhi Nilai Impor Kedelai Indonesia. Buletin Ilmiah Litbang Perdagangan, 8(1),117-138.Retrieved October $13^{\text {th }}, 2017$, from www.kemendag.go.id/files/pdf/2014/11/19/1416397138.pdf.

Nasution (2003). Metode Research. Jakarta: PT.Bumi Aksara.

Pasaribu, T.W. \& Daulay, M. (2013, February). Analisis Permintaan Impor Bawang Merah Idonesia. Jurnal Ekonomi dan Keuangan,1(4),14-26. Retrieved October $7^{\text {th }}, 2017$,from http://jurnal.usu.ac.id/index.php/edk/article/view/9102.

Putera, T. (2016). Analisi Pengaruh Inflasi, Kurs,PDB, Cadangan Devisa dan PMA Terhadap Nilai Impor di Indonesia 2009:Qi-2014:Q4.. Undergraduate thesis,Universitas Lampung, Bandar Lampung.

Rachmanti, A., Riyadi \& Suharmanto (2016). Pengaruh Inflasi dan Nilai Tukar Rupiah Terhadap Impor Kedelai di Jawa Tengah (Periode 2001-2013). JOBS (Journal of Business Studies),185-196.Retrieved November 27th , 2017,from jurnal.polines.ac.id/index.php/jobs/article/view/654/571.

Revania, L. (2014, March).Analisis Faktor-faktor yang Mempengaruhi Impor Jagung di Indonesia Tahun 19822012. JEJAK (Journal of Economic and Policy), 7(1), 102-112. Retrieved October 14th , 2017 , from http://journal.unnes.ac.id/artikel_nju/jejak/3847.

Santosa, P. B. \& Ashari (2005).Analisis Statistik dengan Mikrosoft Exel \& SPSS. Yogyakarta: Andi Offset.

Santosa, S. (2012). Paduan Lengkap SPSS Versi 20. Jakarta: PT.Elex Media Komputindo.

Sasono, H. (2013).Manajemen Pelabuhan dan Realisasi Ekspor Impor. Yogyakarta: Andi Offset.

Sasono, H. (2011). Manajemen Impor dan Iportasi Indonesia. Yogyakarta: Andi Offset.

Sekaran, U. (2011). Metode Penelitian untuk Bisnis Edisi 1 dan 2. Jakarta: Salemba Empat.

Setiawan, H. (2016). Belajar Finance. Bogor: Herya Media 
Sugiono (2010).Metode Penilitian Pendidikan Pendekatan Kuantitatif, Kualitatif dan R\&D. Bandung: Alfabeta.

Sukirno, S. (2000). Makroekonomi Teori Pengantar Edisi Kedua. Jakarta: PT. Raja Grafindo Persada.

Supardi. (2005). Metodologi Penelitian Ekonomi dan Bisnis. Cetakan Pertama Yogyakarta: UII Press.

Sultan, z. (2011, July). Foreign Exchange Reserves and India's Import Demand: A Cointegration and vector Error Correction Analysis. Internasional Jounal of Business and Management, 6(7), 69-76. Retrieved November 27th , 2017,from http://www.ccsenet.org/journal/index.php/ijbm/article/view/8949.

Syamsuddin \& Damaianti, V (2009). Metodologi Penelitian Pendidikan Bahasa. Bandung: PT Remaja Rosdakarya.

Yusgiantoro, p. (2004). Manajemen Keuangan Internasional: Teori dan Praktik. Penerbitan Fakultas Ekonomi Uniersitas Indonesia.

Zaeroni, R. \& Rustariyuni, S. (2016, October). Pengaruh Produksi Beras, Konsumsi Beras dan Cadangan Devisa Terhadap Impor Beras di Indonesia. E-Jurnal Ekonomi Pembangunan Universitas Udayana, 5(9),993-1010. Retrieved October 28 ${ }^{\text {th }}, 2017$, from https://ojs.unud.ac.id/index.php/eep/article/view/23376.

\section{Website}

https://finance.detik.com/berita-ekonomi-bisnis/d-2993556/ini-dia-5-negara-asal-bawang-putih-impor-diindonesia/4

https://finance.detik.com/berita-ekonomi-bisnis/2514763/indonesia-importir-bawang-putih-terbesar-di-dunia http:/ekonomi.kompas.com/read/2017/05/26/082045326/harga.bawang.putih.yang.mengagetkan

https://finance.detik.com/berita-ekonomi-bisnis/3499630/kenapa-ri-masih-impor-bawang-putih-inikatamendag

https://finance.detik.com/berita-ekonomi-bisnis/3509233/kebutuhan-terus-naik-pasokan-bawang-putih-impormalah-turun

http://bali.tribunnews.com/2017/05/13/dulu- -bawang-putih-melimpah-dan-murah-kini-ri-bergantung-padacina-dan-india

http:/ekonomi.kompas.com/read/2017/05/13/105229526/dulu.swamsembada.bawang.putih.melimpah.dan.mu rah.kini.ri.bergantung.pada.cina.dan.india

https://finance.detik.com/berita-ekonomi-bisnis/3114498/20-tahun-lalu-ri-swasembada-bawang-putihsekarang-jadi-importir

https://www.indoneisa.investments.com/id/keuangan/angka-ekonomi-makro/inflasi-di-indonesia/item254?

http://www.indexbox.co.uk/news/which-country-imports-the-most-garlic-in-the-world

https://www.academia.edu/8732972/TEORI-TEORI_PERDAGANGAN_INTERNASIONAL

http://sinausethithik.com/2015/03/03/pengaruh-fluktuasi-nilai-tukar-terhadap-ekspor-dan-impor

https://bintangkecilungu.wordpress.com/2010/10/31/metode-penelitiankorelasional-2/

https://www.bps.go.id/

www.x-rates.com/average

pusatdata.kontan.ac.id/makroekonomi/devisa

www.bi.go.id

www.investopedia.com

www.wikipedia.com 